\title{
Pemikiran Fazlur Rahman Mengenai Politik Islam
}

\section{Fazlur Rahman's Thinking About Islamic Politics}

\author{
Ryzka Dwi Kurnia \\ Institut Agama Islam Negeri Langsa \\ Email: ryzkadwikurnia@iainlangsa.ac.id
}

\begin{abstract}
Abstrak
Fazlur Rahman merupakan seorang pemikir neo-modernisme Islam yang ingin mengaktualisasikan ajaran-ajaran Islam dalam suatu kerangka yang utuh dan kokoh, dimana antara aspek yang satu dan yang lainnya saling berkaitan. Melalui pendekatan ini, ia menginginkan agar Al-Quran dipahami secara integral dan totalitas, sehingga hal-hal yang dianggap bertentangan tidak ada lagi. Upaya ini merupakan obsesinya agar manusia bisa menangkap pesan-pesan Al-Qur'an secara holistik. Berangkat dari keprihatinan terhadap persoalan global yang sedang dihadapi umat Islam, dia menawarkan suatu solusi yang berpijak pada perbedaan antara Islam normatif dan Islam sejarah. Dari pembedaan ini, Fazlur Rahman mengadakan rekontruksi terhadap keilmuan Islam secara menyeluruh. Rekontruksi yang ia lakukan merujuk kepada Islam yang orisinal dan pasti. Untuk itu, ia menyarankan agar Al-Qur'an sebagai sumber utama agama Islam perlu ditafsirkan secara menyeluruh dan bukan menafsirkannya secara fragmentarisme (ayat perayat), yaitu penafsiran yang mampu memahami Al-Qur'an secara utuh, sehingga aspek teologis, hukum, politik maupun etika dalam ajaran Al-Qur'an menjadi satu keseluruhan yang padu. Fazlur Rahman mengemukakan bahwa tujuan Al-Qur'an adalah menegakkan sebuah tatanan masyarakat ethis dan egalitarian. Jadi, masyarakat Islam terbentuk karena ideology Islam. Kondisi ideal tatanan masyarakat Islam itu adalah "yang menyeru kepada kebaikan dan mencegah kejahatan". Hal ini demi mewujudkan pelaksanaan politik yang berdasarkan ideologi Islam yang tidak terlepas dari Al-Qur'an dan sunnah.
\end{abstract}

Kata Kunci: Fazlur Rahman, Politik, Islam

\begin{abstract}
Fazlur Rahman is a thinker of Islamic neo-modernism who wants to actualize the teachings of Islam in a unified and solid framework, where one aspect and the other are interrelated. Through this approach, he wants the Qur'an to be understood in an integral and total way, so that things that are considered contradictory no longer exist. This effort is his obsession so that humans can capture the messages of the Qur'an holistically.
\end{abstract}


POLITICA:

Jurnal Hukum Tata Negara dan Politik Islam

Volume VIII, Nomor II

Halaman 1-16

P-ISSN 2477-2844 E-ISSN 2615-5745

Departing from his concern for the global problems facing Muslims, he offers a solution that is grounded in the differences between normative Islam and historical Islam. From this distinction, Fazlur Rahman conducted a comprehensive reconstruction of Islamic scholarship. The reconstruction he did refers to the original and definite Islam. For this reason, he suggested that the Qur'an as the main source of Islam needs to be interpreted as a whole and not to interpret it fragmentarism (paragraph verses), namely an interpretation that is able to understand the Qur'an as a whole, so that the theological, legal, political aspects and ethics in the teachings of the Qur'an into a unified whole. Fazlur Rahman argues that the purpose of the Qur'an is to establish an ethical and egalitarian society. So, Islamic society is formed because of Islamic ideology. The ideal condition of the Islamic social order is "which calls for good and prevents evil". This is in order to realize the implementation of politics based on Islamic ideology which cannot be separated from the Qur'an and Sunnah.

\section{Keywords: Fazlur Rahman, Politics, Islam}

\section{Pendahuluan:}

Pembahasan mengenai pemikiran politik dalam khasanah ilmu politik, bukanlah hal yang baru. Ini biasa diruntun dari sejarah pemikiran politik yang ada, baik klasik maupun pertengahan maupun modern. Tentu saja para pemikir juga mempengaruhi dan dipengaruhi oleh arus pemikiran zamannya. Adapun wacana mengenai pembebasan berfikir belakangan ini sangat popular dikalangan generasi muda. Fenomena ini merupakan tampilan dari realitas serupa di negara-negara berkembang. Wacana ini terbit setelah modernism dinilai tak mampu lagi merespon seluruh dimensi kehidupan manusia. Modernisme sebagai narasi besar dianggap tidak cukup tangguh lagi menjawab permasalahan yang muncul.

Diskursus mengenai problematika masyarakat dan pembebasan, banyak melahirkan pemikir-pemikir Islam dengan latarbelakang yang tak jauh berbeda. Mereka 
POLITICA:

Jurnal Hukum Tata Negara dan Politik Islam

Volume VIII, Nomor II

Halaman 1-16

P-ISSN 2477-2844 E-ISSN 2615-5745

prihatin dengan kondisi kaum muslimin yang memiliki konsep ideologi (aqidah) sedemikian maju justru tidak berkembang dalam ideologi tersebut. Fazlur Rahman adalah salah satu diantara sekian pemikir tersebut.

Keterlibatan Fazlur Rahman dalam membangun Pakistan dapat dilihat, misalnya, dari konsep ijtihad yang dalam pandangannya merupakan pengguna daya pikir untuk mengahasilkan solusi yang baru terhadap masalah-masalah berdasarkan dasar-dasar dari prinsip Islam.

Dalam kehidupan politik, Fazlur Rahman langsung terlibat dalam kekuasaan di pemerintahan. Hal ini dibuktikan ketika presiden Ayyub Khan memintanya untuk memimpin lembaga riset Islam dan pada tahun 1964 sebagai Dewan Penasehat Ideologi Islam. Ia berusaha mengabdikan dirinya untuk mewujudkan cita-cita itu, yaitu membangkitkan kembali visi Al-Qur'an dari puing-puing reruntuhan sejarah. Pemikiran Fazlur Rahman sering kali menuaikan kontroversi dikalangan masyarakat Pakistan. Hal ini merupakan suatu hal yang menarik untuk diangkat menjadi sebuah tulisan.

\section{Metode}

Sebagai suatu penelitian terhadap kajian pemikiran seorang tokoh dalam kurun waktu tertentu, maka penelitian ini menggunakan pendekatan sejarah (historical approach) dengan memfokuskan pada penelitian peristiwa sejarah. Karena itu, penelitian ini merupakan penelusuran terhadap pemikiran politik Islam yang terjadi dalam kurun waktu dan wilayah tertentu, Sehingga penelitian ini menggunakan pendekatan sejarah, dalam hal ini yang dimaksud adalah "Pemikiran Fazlur Rahman Mengenai Politik Islam".

Selain pendekatan diatas metode yang digunakan adalah pendekatan hermeneutik sebagaimana yang diangkat oleh Emilio Betti merupakan aktivitas interprestasi terhadap suatu objek yang mempunyai makna (meaning-fulls form) dengan tujuan menghasilkan pemahaman yang lebih objektif. Setelah penulis memperoleh data-data yang diperlukan kemudian menganalisis dengan metode deskriptif, yakni memberikan gambaran secara 
POLITICA:

Jurnal Hukum Tata Negara dan Politik Islam

Volume VIII, Nomor II

Halaman 1-16

P-ISSN 2477-2844 E-ISSN 2615-5745

apa adanya, metode deduktif, yakni mengambil kesimpulan dari yang umum kepada yang khusus dan induktif, yakni mengambil kesimpulan dari yang khusus kepada yang umum.

\section{Hasil dan Pembahasan}

\section{Biografi}

Fazlur Rahman lahir di Hazara pada 21 September 1919 M/1338, di daerah Punjab, di dekat anak benua Indo-Pakistan yang sekarang terletak di sebelah bagian barat laut Pakistan. Keluarganya menganut mazhab Hanafi yang cukup kuat. Oleh sebab itu, ia menjelaskan bahwa ia terbiasa menjalankan ibadah seperti shalat serta berpuasa sejak masa anak-anak.

Dasar pemahaman keagamaan keluarganya yang cukup kuat itu dapat ditelusuri dari ayahnya yang bernama Maulana Shihab ad-Din, seorang ulama tradisional kenamaan lulusan Dar al-'Ulum, Deoband. Maulana Shihab ad-Din sendiri adalah seorang ulama modern, meskipun terdidik dalam pola pemikiran Islam tradisional. Ayahnya ini memiliki keyakinan bahwa Islam melihat modernitas sebagai tantangan-tantangan dan kesempatan-kesempatan yang harus dihadapi. Keyakinan seperti ini pulalah yang kemudian dimiliki dan mewarnai kehidupan dan pemikiran Fazlur Rahman.

Bekal dasar tersebut di atas memiliki pengaruh signifikansi yang cukup berarti dalam pembentukan kepribadian dan intelektualitas Fazlur Rahman pada masa-masa selanjutnya. Melalui didikan ayahnya, Fazlur Rahman menjadi sosok yang cukup tekun untuk menimba pengetahuan dari berbagai sumber dan media, termasuk karya-karya Barat. Pengajaran dan pendidikan tradisional ilmu-ilmu keislaman pada waktu kecil beliau terima dari ayahnya Maulana Shihab ad-Din di rumah.

Pada usia 10 tahun, Rahman pun dapat menghafal Alquran. Selanjutnya pada usia 14 tahun, ia sudah mulai belajar filsafat, bahasa Arab, teologi, hadits dan tafsir. Apalagi setelah beliau menguasai beberapa bahasa asing, seperti bahasa Persia, Urdu, Inggris, Perancis, Jerman, Latin dan Yunani, semakin memperteguh kualitas intelektualitasnya. Pengaruh ayah dan ibunya tersebut sangat kuat dalam membentuk kerangka 
POLITICA:

Jurnal Hukum Tata Negara dan Politik Islam

Volume VIII, Nomor II

Halaman 1-16

P-ISSN 2477-2844 E-ISSN 2615-5745

pemikiran dan pengamalan keagamaan Fazlur Rahman. Sang ayah yang dididik dalam pola pemikiran Islam tradisional namun toleran terhadap nilai-nilai modernitas sebagai kenyataan sehari-hari. Dari ibunya diajarkan nilai-nilai kebenaran, kasih sayang, ketabahan dan cinta. Kedua orangtuanya ini ikut memberikan bekal yang cukup signifikan dan mendasar terhadap pembentukan kepribadian dan keintelektualan Fazlur Rahman pada masa selanjutnya.

Hal lain yang mempengaruhi Fazlur Rahman adalah tradisi mazhab Hanafi yang dianut oleh keluarganya dan ini yang membentuk pola pemikirannya dalam hal keagamaan. Tradisi mazhab Hanafi dikenal sebagai salah satu mazhab Sunni yang mengedepankan akal-logika. Ini menjadi modal landasan berpikir Fazlur Rahman untuk selalu berada di lajur pemikiran keagamaan yang bercorak rasional. Meskipun demikian, beliau tidak mau dikungkung oleh satu mazhab tertentu.

Pemikiran keagamaan Fazlur Rahman juga banyak dipengaruhi pola pemikiran kalangan modernis dan sedikit tokoh-tokoh liberal Pakistan sebelumnya sebagaimana yang diajarkan oleh Syah Waliyullah ad-Dihlawi (1703-1762 M), Sayyid Ahmad Khan (1817-1898 M), Sayyid Amir Ali (1849-1928 M), dan Muhammad Iqbal (1977-1938 M), pada masa ini umat Islam di India sedang bergejolak dan berjuang membentuk negara sendiri yang bebas dari India, yaitu suatu negara yang berlandaskan ajaran Islam.

Pada tahun 1940, Fazlur Rahman menyelesaikan studinya pada program Bachelor of Art. Dan dua tahun kemudian ia meraih gelar Master dalam bahasa Arab. Kedua gelar ini diperolehnya dari Universitas Punjab, Lahore. Namun gelar yang diperoleh dari perguruan tinggi di anak-benua India itu tampaknya lebih bersifat formalitas-akademia dibandingkan dengan aspeknya yang bersifat intelektual. Hal ini terbukti dari pernyataannya sendiri bahwa Pakistan tidak dapat menciptakan suatu dasar intelektual. tentunya yang dimaksudkan dengan pernyataan-nya itu ialah dalam pengertian dasar intelektual yang memadai. Kritiknya terhadap sistem pendidikan Islam tercermin dari ungkapannya berikut: "Bila bahan bakar minyak bumi lenyap dari dunia, mungkin ada gantinya. Tetapi bila Islam yang lenyap, gantinya tidak akan ada lagi.” Hal 
POLITICA:

Jurnal Hukum Tata Negara dan Politik Islam

Volume VIII, Nomor II

Halaman 1-16

P-ISSN 2477-2844 E-ISSN 2615-5745

ini menunjukkan komitmen dan keprihatinan Fazlur Rahman terhadap kondisi pendidikan dan intelektual umat Islam pada masa itu.

a. Pengembaraan Intelektual Pertama

Setelah memperoleh gelar Master of Art dari Universitas Punjab pada tahun 1946, ia melanjutkan studi ke Universitas Oxford Inggris, walaupun pada saat itu terdapat anggapan di kalangan umat Islam bahwa belajar ke Barat adalah sesuatu yang naif. Namun Fazlur Rahman tetap pada pendiriannya didasarkan atas ketidakpuasannya terhadap mutu pendidikan di negara-negara muslim, termasuk di Pakistan.

Di sini, selain mengikuti kuliah, Rahman aktif belajar bahasa-bahasa Barat, seperti bahasa Inggris, Yunani, Latin, Jerman, dan Perancis. Kemampuannya yang cepat menguasai berbagai bahasa sangat membantu memperluas wawasan keilmuannya, khususnya dalam studi-studi Islam melalui penelusuran terhadap literatur yang ditulis para orientalis dalam bahasa-bahasa mereka.

Ketika Pakistan memisahkan diri dari India pada tanggal 14 Agustus 1947 dengan konsep dasar negara Islam, Fazlur Rahman kebetulan sedang menempuh studinya di Oxford University. Itulah sebab nantinya, ketika Ayub Khan tampil sebagai presiden Pakistan melalui suatu kudeta militer, ia berusaha mengakomodir pemikiran tokoh-tokoh Islam konservatif maupun modernis yang salah satunya adalah Fazlur Rahman.

Dalam waktu yang relatif singkat Fazlur Rahman menyelesaikan studinya pada tahun 1949 dengan meraih gelar Philosophy of Doctor (Ph.D) di bawah bimbingan S. Van den Bergh dan Hamilton A. R Gibb dengan disertasi mengenai pemikiran Ibn Sina berjudul Avicenna's Psychology. Pada tahun 1952, ia menerbitkan terjemahannya terhadap salah satu karya monumental Ibn Sina, yakni kitab al-Najat, sehingga mengangkat reputasinya di kalangan sarjana ketimuran.

Setelah meraih gelar doktor, Fazlur Rahman tidak langsung kembali ke negerinya Pakistan, karena ia cemas terhadap kondisi negerinya ketika itu agak sulit menerima kehadiran seorang sarjana keislaman dari Barat. Ia kemudian memutuskan untuk tinggal selama beberapa tahun di Barat dengan mengajar di Universitas Durham, Inggris. Ketika 
POLITICA:

Jurnal Hukum Tata Negara dan Politik Islam

Volume VIII, Nomor II

Halaman 1-16

P-ISSN 2477-2844 E-ISSN 2615-5745

mengajar di Universitas ini, ia berhasil merampungkan karyanya Prophecy in Islam: Philosophy and Orthodoxy, yang diterbitkan pertama kali tahun 1958.

Karya ini dilatarbelakangi oleh kenyataan bahwa selama ini sarjana modern yang mengkaji pemikiran keagamaan umat Islam kurang menaruh perhatian terhadap doktrin kenabian, dan lebih terpusat pada masalah-masalah legal dan sosial praktis. Itulah sebabnya, karya Rahman ini memfokuskan perhatian pada area pemikiran religio-filosofis Islam tersebut.

Selanjutnya Fazlur Rahman pindah dan mengajar di Institute of Islamic Studies, McGill University, Kanada dan menjabat Associate Professor of Philopsophy sampai awal tahun 1960, di sini ia berkenalan dengan Wilfred C. Smith, salah seorang orientalis kenamaan yang ketika itu menjabat sebagai Direktur Institute of Islamic Studies, McGill University.

b. Mengabdi di Tanah Air

Pada tahun 1960, Fazlur Rahman kembali ke Pakistan karena diminta oleh Ayub Khan, Presiden Pakistan untuk ikut berpartiaipasi dalam mem-bangun negara Pakistan. Ketika itu, Pakistan menghadapi kontroversi antara kelompok tradisionalisfundamentalis dengan kelompok modernis. Presiden Ayub Khan, menunjuknya sebagai Direktur pada lembaga penelitian Institute of Islamic Research, yang berkedudukan di Karachi. Melalui lembaga ini, Rahman memprakarsai penerbitan Journal Islamic Studies, yang hingga sekarang secara berkala masih terbit dan merupakan jurnal ilmiah setaraf internasional.

Pada tahun 1962 ketika Fazlur Rahman diminta Presiden Ayyub Khan untuk memimpin Lembaga Riset Islam (Islamic Research Institute), dan tahun 1964 sebagai anggota Dewan Penasehat Ideologi Islam (The Advistory Council of Islamic Ideology), ia berusaha mengabdikan dirinya mewujudkan cita-cita tersebut, yaitu membangkitkan kembali visi al-Quran dari puing-puing reruntuhan sejarah.

Sepanjang tahun 1968, terjadi kerusuhan dan pemogokan di mana-mana yang mengungkapkan keberatan masyarakat terhadap pandangan Fazlur Rahman tentang; (1) 
POLITICA:

Jurnal Hukum Tata Negara dan Politik Islam

Volume VIII, Nomor II

Halaman 1-16

P-ISSN 2477-2844 E-ISSN 2615-5745

Sunnah dan Hadits di mana ia mempertahankan kesahihan dan kenormatifan Sunnah Nabi. (2) Penyembelihan hewan secara mekanis. Pada musim semi tahun 1967, Fazlur Rahman menerima surat dari Kantor Komisaris Tinggi Pakistan di London yang mengabarkan bahwa, pemerintah Inggris meminta Pakistan untuk membuka usaha penyembelihan hewan secara mekanis. Fazlur Rahman kemudian membalas surat tersebut dan mengemukakan bahwa hewan hasil sembelihan mekanis itu halal, serta melampirkan teks fatwa Imam Syafi'i. Namun, secara tidak terduga isi surat Fazlur Rahman itu terbit di media cetak Pakistan tanggal 23 September 1967, sehingga sebagian besar khatib Jum'at mengutuk pandangannya itu. Menanggapi hal itu, bulan September 1968 Fazlur Rahman mengundurkan diri sebagai Direktur Lembaga Riset Islam. Pada tahun 1969, ia juga melepaskan keanggotaannya dari Dewan Penasihat Ideologi Islam. Karena ada tawaran mengajar dari University of California, Los Angeles (UCLA), akhirnya mendorong Fazlur Rahman untuk berhijrah ke Amerika, sebagai aktualisasi pemikiran kelak.

c. Pengembaraan Intelektual Kedua

Salah satu alasan hijrahnya Fazlur Rahman ke Los Angeles, Amerika Serikat dapat dilacak pada sikapnya yang realistis dan sekaligus idealis. la menyadari gagasan-gagasan yang ditawarkannya tidak pernah menemukan lahan yang subur di Pakistan. Padahal menurut tokoh ini, vitalitas karya intelektual sangat tergantung pada suatu lingkungan intelektual yang bebas. Gagasan yang bebas dan gagasan itu sendiri adalah dua kata yang sinonim. Suatu gagasan tidak akan pernah survive tanpa adanya kebebasan. Jadi, pemikiran atau gagasan tentang lslam sama dengan pemikiran yang lain menuntut adanya kebebasan di mana dalam kondisi itu perbedaan pendapat, konfrontasi pandangan, dan perdebatan antara ide-ide itu dapat dijamin.

Selama di Chicago, Fazlur Rahman mencoba mencurahkan seluruh aktivitas kehidupannya pada dunia keilmuan. Seluruh kegiatannya hanya berkisar pada aktivitas yang berkaitan secara langsung dengan aspek keilmuan. Bahkan kehidupannya 
POLITICA:

Jurnal Hukum Tata Negara dan Politik Islam

Volume VIII, Nomor II

Halaman 1-16

P-ISSN 2477-2844 E-ISSN 2615-5745

banyak dihabiskan di perpustakaan pribadinya yang terletak di basement rumahnya yang terletak di Neperville, kurang lebih 70 kilometer dari Universitas Chicago. la sendiri dengan bercanda menggambarkan dirinya seperti seekor ikan yang naik ke atas hanya untuk mendapatkan udara.

Konsistensi dan kesungguhan Fazlur Rahman dalam dunia intelektual dapat dibuktikan dari pengakuan lembaga keilmuan yang berskala internasional. Misalnya, pada tahun 1983 ia menerima penghargaan Giorgio Levi Della Vida dari Gustave E. Von Grunebaum Center for Near Eastern Studies, Universitas California, Los Angeles. Fazlur Rahman adalah orang Islam pertama dan satu-satunya (sampai meninggalnya) yang menerima penghargaan itu.

Pada pertengahan dasawarsa delapan puluhan kesehatan Fazlur Rahman mulai terganggu karena penyakit kencing manisdan jantung yang dideritanya. Bahkan ketika dokter pribadinya telah memberikan lampu kuning agar mengurangi kegiatannya, ia tetap memenuhi undangan pemerin-tah Republik Indonesia pada musim panas 1985. Di Indonesia, Fazlur Rahman tinggal selama 2 bulan, melihat keadaan Islam di negeri ini sambil beraudiensi, berdiskusi, dan memberi kuliah di beberapa tempat. Akhirnya, pada tanggal 26 Juli 1988 ia wafat di Amerika Serikat dalam usia 69 tahun setelah beberapa lama sebelumnya ia dirawat di Rumah Sakit Chicago.

2. Karya-Karya

Kajian dan penelusuran terhadap karya-karya Fazlur Rahman dianggap perlu dalam rangka mencari benang merah gagasan dan pemikirannya yang dibahas dalam tulisan ini. Dalam pembahasan ini, karya-karya yang dihasilkannya yang lebih dari seratus buah, tidak akan diungkap dan dijelaskan semua. Pembahasan hanya ditekankan kepada beberapa karyanya yang dianggap mewakili gagasan sentralnya.

Karya orisinal Fazlur Rahman yang berbentuk buku adalah:

a. Prophecy in Islam: Philosophy and Orthodoxy, yang diterbitkan oleh George Allen and Unwire Ltd., London pada tahun 1958. Dalam buku ini, ia membandingkan antara pandangan kaum filosof dan ahli kalam atau teolog ortodoks mengenai konsep kenabian dan wahyu. 
POLITICA:

Jurnal Hukum Tata Negara dan Politik Islam

Volume VIII, Nomor II

Halaman 1-16

P-ISSN 2477-2844 E-ISSN 2615-5745

b. Karya Fazlur Rahman bersifat historis adalah bukunya yang berjudul Islamic Methodology in History, yang pada mulanya ditulis dalam bentuk artikel-artikel yang dipublikasikan dalam jurnal Islamic Studies, mulai bulan Maret 1962 sampai juni 1963, ketika ia di Pakistan. Karya ini bertujuan untuk memperlihatkan evolusi historis terhadap aplikasi prinsip-prinsip dasar pemikiran Islam yang empat: Alquran, Sunnah, ijtihad, dan ijma', yang menjadi kerangka bagi semua pemikiran Islam, selain untuk menunjukkan peran aktual keempat unsur tersebut dalam perkembangan Islam.

c. Buku Fazlur Rahman yang lain yang berjudul "Islam", ia berusaha menjadikan Islam sebagai agama yang hidup melalui pembedaan antara yang normatif dan historis. Buku ini diterbitkan pertama kali tahun 1966 oleh Holt, Rinehart dan Winson. Pada tahun 1968, kembali diterbitkan pada edisi The Anchor Book tanpa ada perubahan. Kemudian pada tahun 1979 terbit edisi kedua yang diberi tambahan epilog. Dalam buku ini, Fazlur Rahman menyajikan perkembangan Islam selama empat belas abad perjalanan sejarahnya. la mengawali bahasannya dari sejarah Nabi Muhammad, kemudian dilanjutkan tentang Alquran, sunnah, hukum, teologi, filsafat, sufisme, sekte-sekte, pendidikan, serta gerakan pembaharuan, dan kemudian diakhiri dengan analisis kritis terhadap warisan Islam.

d. Setelah menulis tentang Ibn Sina pada awal kehidupan intelektualnya, Fazlur Rahman kemudian melahirkan karya berjudul The Philosophy of Mulla Shadra. Melalui buku yang diterbitkan pertama kali oleh State University of New York Press pada tahun 1975 itu, dia memperkenalkan secara kritis dan analitis dari pemikiran religio filosofis Mulla Shadra[30] (w. 1460 M), salah satu tokoh filsafat Islam.

e. Major Themes of the Qur'an, yang edisi pertama diterbitkan pada tahun 1980 oleh Bibliotheca Islamica, Minneapolia, Chicago. Dalam setup wacana intelektual Fazlur Rahman, Alquran selalu dijadikan sebagai sumber rujukan utama. Wacana ini kembali diagungkannya dalam karya Islam and Modernity. Transformation of an Intellectual Tradition, yang diterbitkan pertama kali oleh the University of Chicago Press, 1982. 
POLITICA:

Jurnal Hukum Tata Negara dan Politik Islam

Volume VIII, Nomor II

Halaman 1-16

P-ISSN 2477-2844 E-ISSN 2615-5745

f. Fazlur Rahman kemudian mengangkat masalah kesehatan dan pengobatan dalam perspektif Islam melalui karyanya Health and Medicine in the Islamic Tradition: Change and Identity, yang diterbitkan pertama kali oleh Crossroad, New York, tahun 1987, sebagai karya terakhir, dan lanjutan dari nilai yang terdapat pada karya-karya sebelumnya. Dalam buku ini ia menunjukkan sikap dan pandangan positif Islam dalam menangani masalah-masalah dasar kehidupan umat manusia. Fokus perhatiannya diletakkan pada bidang kesehatan, pemeliharaan dan pengobatan.

Selain karya yang berbentuk buku di atas, masih banyak lagi karya Fazlur Rahman yang lain berupa artikel-artikel yang diterbitkan dalam berbagai jurnal ilmiah. Tidak diragukan lagi, bahwa Fazlur Rahman telah memberikan kontribusi yang cukup berharga bagi pengembangan wacana keislaman modern. Bila ditelusuri lebih lanjut, minimal ada lima aspek yang ditinggalkannya terhadap kajian Islam, khususnya di Amerika Serikat, yaitu:

a. Fazlur Rahman mampu menggabungkan antara tradisionalisme Islam Sunni, modernisme Islam dan skolastisisme Barat.

b. Dalam mencari kebenaran, Fazlur Rahman melakukan inovasi secara berani dan apresiatif di antara sikap Islam dan sikap Barat.

c. Ia mengenalkan metodologi pengkajian Islam yang bersifat interdisipliner.

d. Dengan sikapnya yang gentle, spirit dan intelektulitasnya yang tajam, menjadikan Fazlur Rahman dan pemikiran-nya diterima secara luas dalam pengkajian Islam di Amerika Serikat.

e. Dia telah meninggalkan warisan pemikiran kepada muridnya yang tersebar di berbagai universitas dan perguruan tinggi Amerika Serikat dan Kanada. Melalui muridmuridnya, gagasan-gagasan yang pernah dikemukakan Fazlur Rahman terus berkembang sampai saat ini.

Dengan lima varian yang ditinggalkannya itu, Fazlur Rahman menjadi salah satu tokoh yang cukup berpengaruh di dunia Islam dan Barat. 


\section{Pengertian Politik Islam}

Politik merupakan suatu ilmu pengetahuan mengenai ketatanegaraan seperti tentang "theory of the state", cara pemerintahan, dasar-dasar pemerintahan dan sebagainya. Selain itu, menurut Rod Hague, politik adalah kegiatan yang menyangkut cara bagaimana kelompok-kelompok mencapai keputusan-keputusan yang bersifat kolektif dan mengikat melalui usaha untuk mendamaikan perbedaan-perbedaan di antara anggota-anggotanya.

Sedangkan Islam diartikan sebagai akidah dan syariat. Syariat sendiri mengatur hubungan manusia dengan sesamanya, serta alam sekitarnya (hubungan vertikal, horizontal dan diagonal. Hubungan manusia dengan manusia lainnya, maupun hubungan manusia dengan Tuhannya, kedua-duanya diikat oleh akhlak (moral dan etika). Moral Islam menyangkut segi-segi ibadah, muamalah, individual dan sosial serta mengatur tata hidup dan kehidupan pribadi keluarga, masyarakat dan negara, di atas landasan:

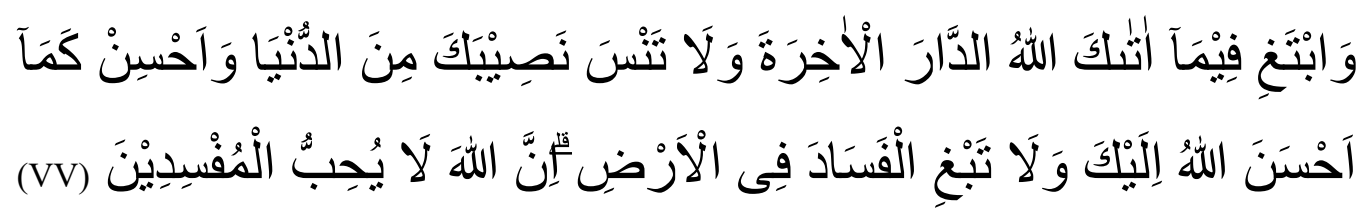

Artinya: Dan carilah (pahala) negeri akhirat dengan apa yang telah dianugerahkan Allah kepadamu, tetapi janganlah kamu lupakan bagianmu di dunia dan berbuatbaiklah (kepada orang lain) sebagaimana Allah telah berbuat baik kepadamu, dan janganlah kamu berbuat kerusakan di bumi. Sungguh, Allah tidak menyukai orang yang berbuat kerusakan. (Q.S. Al-Qashash: 77)

Oleh sebab itu, tidak benar jika dikatakan bahwa hubungan antara agama dan politik tidak lebih dari hubungannya dengan ibadah. Karena politik itu sendiri tercakup di dalam makna ibadah. Adapun sebagaimana ayat-ayat Al-Qur'an membicarakan masalah- 
POLITICA:

Jurnal Hukum Tata Negara dan Politik Islam

Volume VIII, Nomor II

Halaman 1-16

P-ISSN 2477-2844 E-ISSN 2615-5745

masalah seperti wilayah, kekuasaan, hukum, peperangan, pengadilan, undang-undang, kriminalitas, bahkan persoalan seperti perkawinan, keluarga, jual-beli, hutang, persaksian, qishas, hubungan internasional, penjara atau tawanan, mawaris dan lain sebagainya merupakan pembicaraan tentang politik.

\section{Pemikiran Fazlur Rahman}

\section{A. Negara}

Menurut teori politik Islam, negara dapat dibentuk apabila ada sekelompok orang yang telah menyatakan bersedia melaksanakan kehendak Allah sebagaimana tercantum dalam wahyu-Nya. Model negara seperti ini telah dikenal dalam sejarah yang pernah dibentuk oleh Nabi Muhammad saw. Dengan adanya kesediaan tersebut, kelompok orang semacam ini berarti telah membentuk umat muslim. Negara adalah organisasi yang mendapatkan kepercayaan dari umatnya untuk mengemban tugas dalam rangka memenuhi keinginan umat itu. Karena itu tidak dapat diragukan lagi bahwa negara Islam itu mendapatkan jaminan dari rakyat.

Untuk mewujudkan semua itu, pemerintahan negara haruslah dipimpin oleh seorang yang mampu mengelola secara efektif persoalan-persoalan negara, dimana rakyatnya secara sukarela dipimpin oleh pemimpin tersebut. Kepala negara menurut Fazlur Rahman merupakan pusat dari segala kekuasaan eksekutif, kekuasaan sipil dan militer serta kekuasaan yang secara teknis dikenal dengan istilah kekuasaan keagamaan. Jadi, kepala negara merupakan pemegang kekuasaan tertinggi, baik dalam urusan sipil maupun keagamaan dan sebagai penglima tertinggi dari angkatan bersenjata. Namun dengan kedudukannya sebagai penguasa tertinggi urusan keagamaan itu tidak berarti kepala negara lantas seperti Paus, sebab kepala negara tidak dapat menetapkan dogmadogma agama menurut kemauannya sendiri. Fungsi ini tetap berada pada masyarakat secara keseluruhan dengan perantaraan lembaga ijma' di bawah pimpinan para ulama dan para pemikir kreatif lainnya. 
POLITICA:

Jurnal Hukum Tata Negara dan Politik Islam

Volume VIII, Nomor II

Halaman 1-16

P-ISSN 2477-2844 E-ISSN 2615-5745

Fazlur Rahman membuat ide-ide negara Islam untuk diterapkan oleh masyarakat Pakistan. Dimana pada masa itu Pakistan sudah dijajah oleh bangsa asing sehingga seabad lamanya. Dimana pemisahan antara fungsi kepala negara untuk mengurus masalah keagamaan dan sosial lainnya telah menjadi budaya politik pada waktu itu. Maka pada abad pertengahan Fazlur Rahman menganjurkan agar kepala negara yakni pemegang kekuasan pemerintah harus mengambil alih semua kekuasan itu secara utuh tanpa dipecah-pecah.

Fazlur Rahman juga menjelaskan, dikarenakan kepala negara dari suatu negara Islam merupakan pusat kekuatan-kekuatan yang begitu besar yang diamanatkan kepadanya maka dia secara langsung bertanggung jawab kepada mereka. Dengan alasan inilah, kekuasaan ini bisa dijalankan oleh seorang saja asal ia mampu, sanggup bekerja keras dan yang perhatiannya ditujukan kepada masyarakat dan negaranya. Dia haruslah orang yang benar-benar berwibawa dan dihormati oleh rakyat. Perlu dicatat bahwa kesetiaan dan kejujuran, kedua-duanya sangat diperlukan bagi pemegang jabatan kepala negara ini.

Selain itu, Fazlur Rahman juga menekankan tiga komponen penting dari suatu negara Islam yaitu masyarakat muslim, hukum Islam dan pemimpin masyarakat muslim. Karena otoritas mutlak atau kedaulatan atau kedaulatan pokok berada pada Tuhan. Karena negara Islam menjunjung supermasi kehendak utamaNya sebagai dinyatakan dalam hukum Islam.

Fazlur Rahman menyebutkan sebagai urusan pemerintahan, secara jelas Al-Qur'an memeritahkan kaum muslimin untuk menegakkan syura (dewan majelis konsultasi) dimana keinginan rakyat dapat dikemukakan melalui wakil-wakil mereka. Syura ini adalah sebuah institusi Arab yang demokratis dari masa sebelum Islam dan kemudian didukung oleh Al-Quran. Nabi Muhammad sendiri telah diperintahkan dalam Al-Qur'an untuk memutuskan persoalan-persoalan setelah berkonsultasi dengan pemuka-pemuka masyarakat. 
POLITICA:

Jurnal Hukum Tata Negara dan Politik Islam

Volume VIII, Nomor II

Halaman 1-16

P-ISSN 2477-2844 E-ISSN 2615-5745

Selanjutnya Fazlur Rahman menyebutkan bahwa tidak dapat disangkal bahwa dalam sejarah Islam, telah terjadi fraksi-fraksi politik yang didasarkan pada doktrindoktrin agama. Hal ini menyebabkan munculnya sikap dan perilaku tertentu dari golongan-golongan Islam. Berkaitan dengan ini, ia menyatakan bahwa Islam selalu menjadi korban golongan-golongan ekstrim, tidak hanya dibidang politik, tetapi dibidang etika dan teologi. Padahal inti ajaran Al-Qur'an adalah menghasilkan sikap etika yang benar dalam tindakan manusia, baik dalam bidang politik, agama dan sosial.

Fazlur Rahman juga menjelaskan bahwa, jika penyelewengan terjadi pada pimpinan-pimpinan agama, maka itu semua merupakan tahap terakhir di dalam proses keruntuhan masyarakat. Dimana seharusnya, pemimpin-pemimpin itu merupakan sumber kekuatan dari regenerasi spriritual. Untuk itu, secara lugas ia mengemukakan bahwa sangat dibutuhkan kaum muslimin saat ini adalah perhatian yang sehat kepada negara dan kritik yang membngun di dalam masalah pemerintahan dengan mengingat betapa perlunya menjaga integritas kaum muslimin dan stabilitas negara.

\section{B. Modernisme Politik}

Fazlur Rahman menjelaskan bahwa sejak semula akibat dampak ekspansionis Barat terhadap wilayah-wilayah muslim serta kegagalan kaum muslimin dalam melakukan perlawanan militer dan perlawanan politik, menjadikan masyarakat muslim lebih disibukkan dengan masalah reorganisasi politik yang efektif. Hal ini menimbulkan kesadaran terhadap kaum muslimin sendiri dalam melakukan pembaharuan sosial dan modernism politik.

Namun dalam pelaksanaannya menimbulkan kebingungan-kebingungan dikalangan kaum muslim sendiri. Hal ini disebabkan oleh kekuatan-kekuatan politik menurut kepentingan pribadinya sendiri, yang berada dalam persaingan-persaingan yang saling bertentangan secara terus menerus dan mereka bertindak sebagai musuh (yakni mereka yang memaksakan diri mereka ke dalam politik dan ekonomi) maupun sebagai penasehat-penasehat kaum muslimin, dengan gambaran lengkap. 
POLITICA:

Jurnal Hukum Tata Negara dan Politik Islam

Volume VIII, Nomor II

Halaman 1-16

P-ISSN 2477-2844 E-ISSN 2615-5745

Dalam proses modernisasi politik yang terjadi dikalangan kaum muslimin, timbul beberapa ide pembaharuan politik. Salah satunya disuarakan oleh Jamaluddin Al-Afghani yang menyerukan kesatuan dunia (Pan-Islamisme) dan kependudukan muslim. PanIslamisme sendiri bertujuan untuk melawan dominasi asing di wilayah-wilayah muslim. Menanggapi hal itu Fazlur Rahman menyebutkan, meskipun persamaan terhadap PanIslamisme itu kuat namun akan muncul pemaksaan terhadap penekanan nasionalisme terhadap ideologi negara dalam negeri-negeri muslim tertentu.

Namun dalam perkembangan modernism politik dikalangan muslim itu sendiri, Fazlur Rahman dengan keras menolak konsep Sekularisme. Menurutnya, sekularisme itu akan memotong akar-akar Islam dengan dua cara, yaitu: kemungkinan akan merusak kesatuan umat muslim dari luar dan dalam lingkungannya sendiri.

\section{Penutup}

Adapun pemikiran Fazlur Rahman mengenai politik Islam terdiri dari gagasan tentang negara, musyawarah, kepemimpinan serta modernism politik. Ia menjelaskan bahwa Al-Qur'an tidak hanya membahas mengenai persoalan ibadah tetapi juga mengenai urusan dunia. Oleh sebab itu, sudah selayaknya permasalahan politik juga bersumber pada Al-Qur'an dan sunnah. Selain itu ia juga memberikan gagasan mengenai modernisme dalam Islam, dimana ia sangat menolak terhadap hegemoni Barat terhadap kaum muslimin. Sudah selayaknya melakukan reformasi terhadap pemerintahan Islam dan melepaskan diri dari pengaruh Barat. Kemudian ia juga sangat menolak paham sekularisme diantara pemerintahan kaum muslim. Hal ini akan berakibat keruskan akarakar ke-Islaman bagi umat muslim sendiri. Untuk itu, ia mengajak masyarakat muslim untuk segera bangkit melawan penjajahan Barat dan mengembalikan landasan politik terhadap Al-Quran dan sunnah. 
POLITICA:

Jurnal Hukum Tata Negara dan Politik Islam

Volume VIII, Nomor II

Halaman 1-16

P-ISSN 2477-2844 E-ISSN 2615-5745

\section{Daftar Pustaka}

Abd. A'la (2003), Dari Neo-Modernisme ke Islam Liberal :Jejak Fazlur Rabman Dalam Wacana Islam di Indonesia, Jakarta : Paramadina

Taufik A. (1987), Metode dan Alternatif Neomodernisme Islam Fą̧ur Rabman, Bandung: Mizan

Ali F. (1998), Fąlur Rahman Sang Sarjana Sang Pemikir, Jakarta : Lembaga Studi Agama dan Filsafat.

Budiardjo M. (2007), Dasar-dasar Ilmu Politik, Jakarta : PT. Gramedia Pustaka Utama.

Fuad M. (1986), Pemikiran Politik Islam, Jakarta: PT. Raja Grafindo

Fazlur R (1992), Islam, Edisi Indonesia Terjemahan Senoaji, Jakarta : PT Bumi Aksara.

-------------, Islam dan Modernitas: Tentang Transformasi Intelektual, Edisi Indonesia terj. Asin Mohammad, Bandung: Penerbit Pustaka

--------------, Membuka Pintu Ijtihat, Edisi Indonesia Terj. Anas Mahyudi, Bandung: Penerbit Pustaka.

--------------, Tema-tema Pokok Al-Qur'an, Edisi Indonesia, Terj.Anas Mahyudin, Jakarta: Pustaka

----------------, Gelombang Perubahan Dalam Islam, Edisi Indonesia, Terj. Ibrahim Mosa, Jakarta: Rajawali Press 